\title{
THE ROLE OF INTEREST RATES IN INFLUENCING HOUSING PRICES
}

\author{
JOE WONG, EDDIE HUI and \\ WILLIAM SEABROOKE \\ Hong Kong Polytechnic University
}

\begin{abstract}
This paper investigates the role of interest rates on housing prices from the perspective of homeowners' expectations. Using quarterly data on interest rates and housing prices for Hong Kong in 1981-2001, it identifies a structural shift in housing prices coinciding with a move from inflation to deflation around 1997. The results indicate a moderately high correlation between housing prices and nominal interest rates in 1998-2001, as opposed to a negative correlation during the earlier period. The same pattern again holds in linear regression with both interest and inflation as explanatory variables. The Granger causality test indicates that interest rates do not significantly determine housing prices. The study suggests that the interaction between interest rates and expectations of capital gains or losses plays a critical role in the short-run housing price fluctuations in Hong Kong.
\end{abstract}

Keywords: Interest rate, housing prices, price expectations, Hong Kong.

\section{INTRODUCTION}

During the inflationary early 1990s, housing prices in Hong Kong were volatile, yet the upward trend exceeded the rate of inflation. In the fourth quarter of 1997 , the housing price of an "average" size property reached US\$891 per square foot (Hong Kong Property Review). In the same quarter, the monthly median household income in Hong Kong was only US\$2500 (Hong Kong Monthly Digest of Statistics). The strong housing demand for occupation and investment between 1989 and 1997 led to a three-fold increase in housing prices and 94 percent increase in rents. By December 2001, the "average" housing price significantly dropped by 57 percent from the 1997 peak to about US\$385 per square foot (Hong Kong Property Review). Property transactions also decreased by nearly 60 percent in the same period (Hong Kong Land Registry). By the end of 2001, economic confidence sunk to an all-time low, even lower than after the Tiananmen unrest in China in 1989 (DeGolyer et al., 2001). Movements of housing prices, rents and interest rates from 1988 to 2001 are presented in Figure 1.

Pacific Rim Property Research Journal, Vol 9 No 3 
The inflation rate increased from 9.8 percent in 1990 to 12.0 percent in 1991 , while the mortgage interest rate dropped from 12.25 percent to 10.75 percent in the corresponding period. This equated to a decline in the real mortgage rate from 2.45 percent to -1.25 percent. The rate remained negative until March 1994. Lower capital cost was resulted from a series of reductions in interest rates in the USA throughout 2001. The Linked Exchange Rate System ${ }^{1}$ led to a significant decrease by 11 downward increments in nominal interest rate of a total of 4.375 percent to 5.125 percent per annum in 2001 (Hong Kong Monetary Authority), one of the lowest rates in 40 years in Hong Kong (Figure 2).

\section{Figure 1: Housing price \& rent indices \& interest rates in Hong Kong}

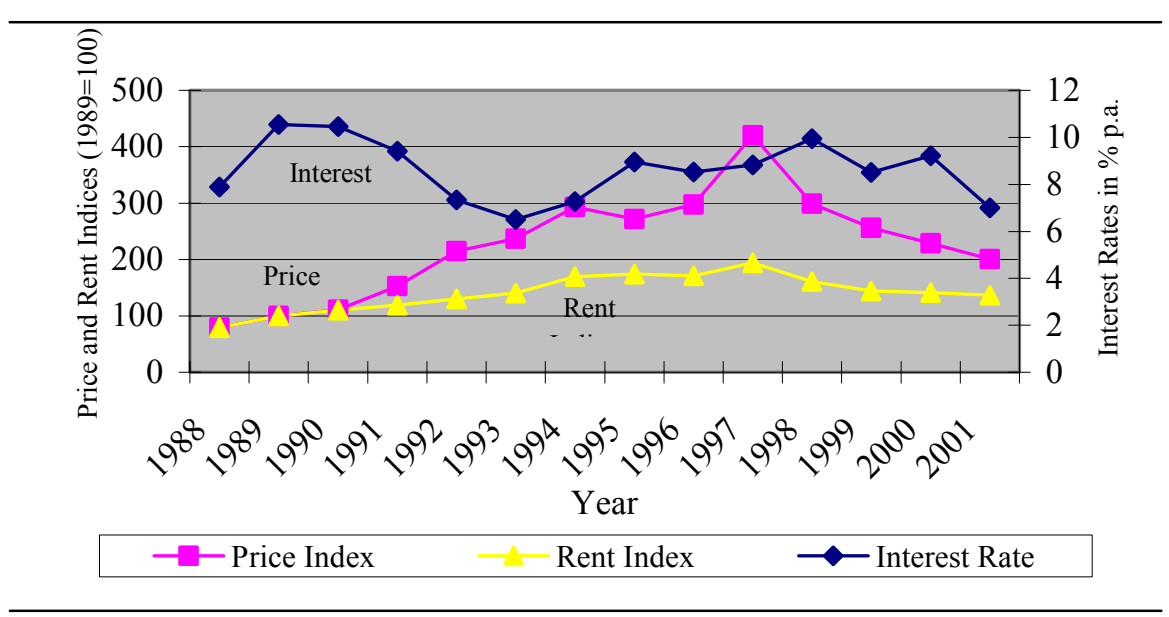

Falling interest rates stimulated the demand for home ownership, as indeed occurred in the 1990s. However, further falling interest rates in 2001 and 2002 did not revive the market. This phenomenon does not support the proposition that low interest rates have a positive effect on both demand- and supply-side variables. This study investigates the separate effects of rising and falling interest rates on housing prices. A number of studies in Hong Kong have examined the positive effect of falling rates in inflationary periods, but few studies have been able to estimate the effect in times of deflation.

\footnotetext{
${ }^{1}$ The Hong Kong dollar has been pegged to the US currency at US\$1 $=$ HK\$7.80 since 7 October 1983. Interest rate movements are, therefore, influenced by US interest rates due to the link of the HK\$ with the US\$ within the framework of this Linked Exchange Rate System.
} 
This paper addresses the following questions: (a) if interest rates are a major factor affecting residential property prices, is its impact the same in periods of inflation ${ }^{2}$ and deflation? (b) In a period of falling real prices, do deflationary expectations matter? And how? (c) Is there any causal relationship between housing prices and nominal interest rates?

Figure 2: Interest rates and inflation rates: 1980-2001

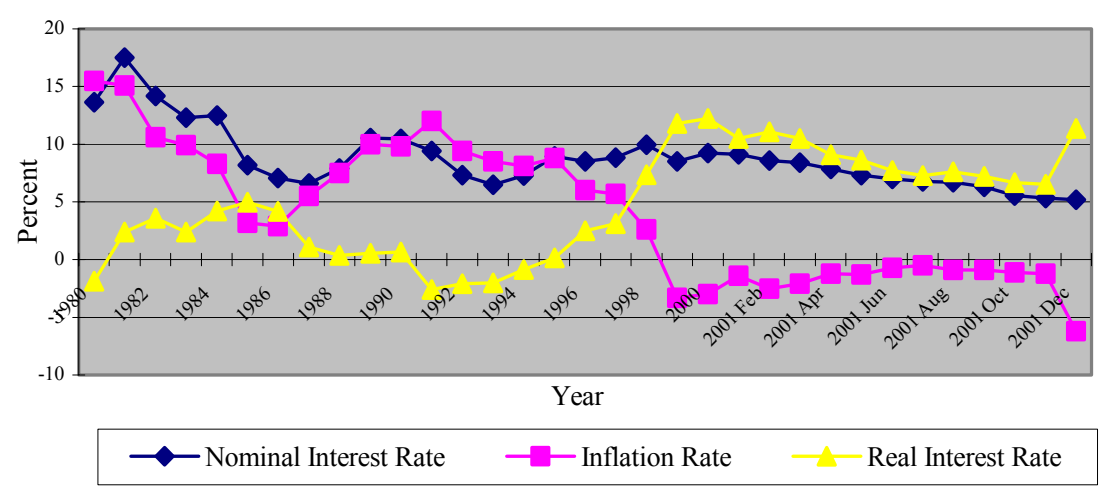

The remainder of the paper is organized as follows: a theoretical literature on interest rates and house prices with reference to expectations is presented in the next section. It is followed by a review of expectation literature in the third section. A discussion of the data and methodology is made in the fourth section. The analysis and empirical results are presented in the fifth section, followed by the implications of the findings. Finally, the last section concludes.

\section{THEORETICAL LITERATURE OF INTEREST RATES AND HOUSE PRICES}

With perfect foresight (rational expectations), the capital value (probable selling price) of an income property represents the value of the total future income stream or services from the property to the homeowners. Future incomes are capitalised to present capital sums at an appropriate discount rate of interest or capitalisation rate. This market extracted capitalisation rate, in essence, assumes a static market with little or no change in price expectations. With perfect foresight and a well-

\footnotetext{
${ }^{2}$ Inflation (or deflation) is a macroeconomic concept referring to an increase (decrease) in the absolute price level over some defined time periods. An increase (decrease) in the price of all goods has the effect of reducing (increasing) the purchasing power of money and money incomes and thus must be taken into account when making investment decision.
} 
functioning capital market, the real rate of interest may be written as the nominal interest rate less the compensation for expected inflation. This follows the relationship between nominal interest rates and real interest rates in the Irving Fisher hypothesis. That is, the nominal interest rate is approximately the sum of the ex-ante real interest rate and expected inflation. The price-expectations, or Fisher, effect is summarised in his original equation:

$$
\mathrm{i}=\mathrm{r}+\left(1 / \mathrm{P}^{*} \mathrm{dP} / \mathrm{dt}\right)+\mathrm{r}\left(1 / \mathrm{P}^{*} \mathrm{dP} / \mathrm{dt}\right)
$$

where $\mathrm{i}$ is the nominal or market rate of interest, $\left(1 / \mathrm{P}^{*} \mathrm{dP} / \mathrm{dt}\right)$ is the expected rate of change of prices, $r$ is the 'real' rate of interest. The third term on the right side is the interest that would be earned on the price adjustment to the nominal rate. This term is frequently insignificant and customarily omitted. Conceptually, the inflation component should reflect a forward-looking (rational approach) measures of expected inflation, as opposed to the backward-looking (adaptive approach) measures commonly used. Fisher posits that people form expectations by taking a weighted sum of current and past actual rates of inflation (i.e., the irrationalexpectations school of macroeconomics).

According to Fisher (1930), interest rates are made up of three components: future time preference, risks and inflation expectations. A simple way to derive this interest rate is to add a premium onto the best lending rate. This rate represents the cost of capital, which is used to guarantee the investor that the rental income can cover the cost of borrowing. Fisher (1930) hypothesised that 'Interest rates tend to be "high" when prices are rising and "low" when prices are falling.'

Following the "user cost" concept used by Mills and Hamilton (1984) $)^{3}$, the true cost of occupying housing is modified to account for gains (losses) from inflationary (deflationary) expectations other than only the cost of interest associated with holding housing capital. This real cost of housing capital is the key element of home purchase, because high interest rates tend to add the real burden of debt payments. This user cost was given a richer urban spatial framework by DiPasquale and Wheaton (1994) in addressing issues related to housing price adjustments, the formation of price expectation and effects of the

\footnotetext{
${ }^{3}$ The relationship can be expressed as:

$\mathrm{R}=\left\{(\mathrm{r}+\Pi)(1-\mathrm{T})-\left(\mathrm{g}^{\mathrm{r}}+\Pi\right)\right\} \mathrm{V}$, or

$\mathrm{V}=\mathrm{R} /\left\{(\mathrm{r}+\Pi)(1-\mathrm{T})-\left(\mathrm{g}^{\mathrm{r}}+\Pi\right)\right\}$
}

where $r$ is the real rate of interest, $\Pi$ is the expected inflation rate, $T$ is the marginal income tax rate, and $\mathrm{g}^{\mathrm{r}}$ is the expected rate of capital gains. For a house of value $\mathrm{V}$ and unit costs given by $\mathrm{r}, \Pi, \mathrm{T}$, and $\mathrm{g}^{\mathrm{r}}, \mathrm{R}$ is the rent that must be charged to cover costs at an acceptable rate of return called the capitalization rate. Clearly, price expectations can change the magnitude of the denominator. If expectations are optimistic, high $\mathrm{g}^{\mathrm{r}}$ at times of inflation suggests the capitalization of these gains in selling the house. On the other hand, if the value of $\mathrm{g}^{\mathrm{r}}$ is small as a result of declining property appreciation, or negative arising from capital losses, home owners are reluctant to sell their houses. 
land factors on housing flows. Harris (1989) concluded that housing prices were affected by real interest rates. Muellauer and Murphy (1996) found that demographic changes and interest rates were two important factors causing the UK house price boom in the late 1980s. In examining the dynamics of housing prices in 130 US metropolitan areas during the 1984-1998 period, Jud and Winkler (2002) found that real housing price appreciation is strongly influenced by the growth of population, income changes, construction costs and interest rates. Tan (1994) found weak uni-directional Granger causality relationships from house prices to interest rates in Singapore, due to its rapid economic growth, public housing policies and high saving rates.

In the local market, Tse (1996) suggested that a declining real interest rate tends to stimulate housing prices. Tse (1996a) concluded that the dramatic increase in housing prices in 1991 in Hong Kong was mainly due to the expectation of rising inflation, fuelled by decreasing interest rates. Another empirical study of Tse (1996b) also illustrated that, during 1984-1994, the interest rate under the Linked Exchange Rate System in Hong Kong had a direct effect on housing prices. In general, the studies of Tse focus on positive effects of falling interest rates on local property markets in the inflationary pre-1997 period. This study, however, points out that falling rates in times only play a supporting role. It provides additional evidence that the interaction of nominal rates and deflationary expectations, the real rate to the borrower, lowers market prices in the deflationary period after the bubble burst.

\section{LITERATURE REVIEW ON PRICE EXPECTATIONS}

Once a price begins to rise, like the early stage of the bubble, people tend to think that the previous rising trend will continue. That is, the price increase is expected. Thus, the price change reflects the expectations of the future trends. For example, Phillips (1988) demonstrated that housing price increases reflect future housing price appreciation rather than expected future increases in rental. Similar studies by Phillips (1985) and McDonald (1985) argued that expected increases in house values may bid up house prices independent of expected rents. Krashinsky and Milne (1987) noted that housing demand responds not only to current prices, but also price expectations. The models of Harris (1989) further suggested that expectations of future appreciation are important determinants of house sale prices, and these expectations remain influential even during periods of declining and moderating real prices. DiPasquale and Wheaton's (1994) model assumed that the fluctuation of prices was caused by the difference between the actual price and expected price. The important interplay between house values and expectations was also noted by Blackadar (1989), who stated that "Market values are opinions, which are the appraiser's: the expectations are those of the marketplace". 
In studying expectations of capital appreciation in the housing market, Capozza (1996) found evidence that total returns assuming that the sum of the rent and the expected capital gain were based on rational expectations. Similarly, Peng and Wheaton (1994) concluded that the appreciation of high future housing rents would be rationally capitalised into higher current housing prices. In the price equation derived by Kim and Suh (1993), the future price was based on rational expectations (forward looking approach) included in the demand function. However, in Brown, Song and McGillivray (1997), adaptive expectations (backward looking approach) were assumed according to the expected capital gain. Muth (1986) used the concept of expectations for the housing price change and argued that the adaptive expectations had explanatory power for the data rather than the rational expectations in the estimated results.

A considerable body of literature establishes positive effects of changes in expected inflation and interest rates on price levels. Little attempt has been made to evaluate the "real" positive effect of a falling interest rate on, and its causal relationship with, housing prices in a deflationary period in Hong Kong. This study attempts to fill this important expectation literature gap by providing comparative evidence in the local context.

\section{METHODOLOGY AND DATA}

This section presents: (a) the hypotheses of the study; (b) the methodology; and (c) sources of data.

\section{Study hypotheses}

For a period of falling real prices in Hong Kong, it is hypothesised that: (a) there is an inverse relationship between housing prices and nominal interest rates in times of inflation and a direct relationship in times of deflation; (b) the effect of interest rates on housing prices differs significantly in inflationary and deflationary periods; strongly on the former and weakly on the latter; and (c) there is no causal relationship between housing prices and interest rates.

\section{Research methodology}

Three procedures were used to explore the relationship between interest rates and housing prices, and to evaluate the effect of the former on the latter. First, a multivariate correlation model was used to test hypothesis (a). It was done by calculating the Pearson product-moment correlation between each pair of variables of housing price levels and nominal interest rates, real interest rates and inflation rates. Second, a regression analysis was performed to test hypothesis (b). The differing effects were found by using the equation that best represents the linear relationship between these two variables. Finally, a Granger causality test 
for hypothesis (c) was performed to test the presence of cause-and-effect relationships of time-series models.

The regression may be spurious if it involves non-stationary time series data. Therefore, Granger causality tests require the use of stationary time series data (Granger and Newbold, 1974). If a variable contains a unit root, then it is nonstationary over time, following a random walk process. It may reach stationarity by differencing $\mathrm{t}$ times, then the variable is referred as an $I(\mathrm{t})$. The test for unit roots involves the simple Dickey-Fuller (DF) and Augmented Dickey-Fuller (ADF) Tests. An ADF Test is based on the following regression equation:

$$
\Delta \mathrm{Y}_{\mathrm{t}}=\alpha+\beta_{\mathrm{t}}+\gamma \mathrm{Y}_{\mathrm{t}-1}+\sum_{\mathrm{i}=1}^{\mathrm{n}} \eta_{\mathrm{i}} \Delta \mathrm{Y}_{\mathrm{t}-1}+\mu_{\mathrm{t}}
$$

where $\mathrm{Y}$ is the variable under estimation, $\Delta \mathrm{Y}_{\mathrm{t}}$ is $\mathrm{Y}_{\mathrm{t}}-\mathrm{Y}_{\mathrm{t}-1}, \alpha$ is the drift term, $\beta_{\mathrm{t}}$ is the time trend with the null hypothesis of $\mathrm{H}_{0}: \gamma=0$ (unit root exists) and its alternative hypothesis of $\mathrm{H}_{1}: \gamma \neq 0, \mathrm{n}$ is the number of lags necessary to obtain white noise, and $\mu_{\mathrm{t}}$ is the white noise.

One of the assumptions of regression analysis is that the residuals for cumulative observations are uncorrelated. A common problem in time series data is the positive autocorrelation indicated by the expected value of the Durbin-Watson statistic being less than 2. The critical value of Durbin-Watson d, at any significance level, depends on the number of observations in the sample and the number of explanatory variables. To avoid violation of the assumption, it is essential to carry out the Durbin-Watson Test of the autocorrelation of AR(1) type. If the Durbin-Watson d statistic lies between 1.59 and 2.41, we do not reject the null hypothesis of no autocorrelation.

Another important assumption of any time series model is that the underlying process is the same across all observations in the sample. In the study, there are two sub-periods: 1981-1997 and 1998-2001. We need to use the Chow Test ${ }^{4}$ (1960) for structural breaks in some or all of the parameters of a model. If we reject the null hypothesis of no differences, then there are differing slopes and intercepts of the regressions for the two neighborhood, meaning that we cannot simply "pool" the data, and ignore the neighborhood effects. If that is the case, pooling the data would be equivalent to imposing restrictions or constraints on

\footnotetext{
${ }^{4}$ For the Chow Test, we can calculate ESS1, ESS2 and ESS3 (error sum of squared residuals) for periods 1981-1997, 1998-2001 and 1981-2001, respectively. From three regressions, we constructed the F-statistic, $\mathrm{F}=[(\mathrm{ESS} 3-(\mathrm{ESS} 1+\mathrm{ESS} 2)) / \mathrm{k}] /[(\mathrm{ESS} 1+\mathrm{ESS} 2) /(\mathrm{N} 1+\mathrm{N} 2-2 \mathrm{~K})]$, where N1 and N2 are observations of the periods 1981-1997 and 1998-2001, respectively and $\mathrm{K}$ is the number of parameters. If $\mathrm{F}$ is greater than $\mathrm{F}$ critical (or $\mathrm{F}(\mathrm{K}, \mathrm{N} 1+\mathrm{N} 2-2 \mathrm{~K})$ ), we can reject the null hypothesis, implying regression parameters and variances of the error terms are not the same for both periods.
} 
housing price functions to be the same for two periods, which are not true, on the parameters. It makes the least squares estimator biased and inconsistent, no matter how large the sample.

It should be noted that the time series data used in the analysis are ratio scales rather than ordinal numbers. In measuring the linear association between two variables, we selected the Pearson product moment correlation (r) as an appropriate inferential statistic for associational hypothesis. The parametric statistic was therefore computed for all three sub-periods in 1981-2001. Housing price data in 1981-1997 are only available in the quarterly basis from the Property Review. To ensure consistency in the study periods, 68 quarterly data sets for 1981-1997, 16 sets for 1998-2001, and 84 sets for 1981-2001 were used. In view of the small sample in 1998-2001, which might violate the assumption of the Pearson correlation (such as normality of the raw data), we also computed the non-parametric Spearman rank-correlation coefficients in 1998-2001 for comparison purposes.

A dependent variable "Levels of Housing Prices" of "all classes" of private domestic units territory-wide was regressed against "Nominal Interest Rates" for the overall 1981-2001 period and the two sub-periods: 1981-1997 and 19982001. It is necessary to segregate the study period into these two sub-periods, so as to differentiate the effect originally hypothesised before and after the hand-over of Hong Kong to Mainland China on 1 July 1997 and the Asian economic crisis by end of 1997. Further, the period chosen spans over a complete "trough" and a prolonged "peak" period of the property cycle in Hong Kong. It also covers a major structural change in the financial sector associated with the linked exchange rate to the US currency. Estimation was made by least squares of "Levels of Housing Prices" on "Expected Inflation Rates", and then on "Expected Real Interest Rates" separately for the aforesaid three periods. Individual models were evaluated on the general goodness of fit, regression coefficients exhibiting the expected sign and significance of the explanatory power of the independent variables.

A Bivariate Granger Causality Test was performed to test the direction of causality in price-interest relationships for three periods. A causality running from interest rates to housing price levels may suggest that interest rate changes represent the leading impact of the information on housing prices. Granger causality is important because it allows us to analyse which variable precedes or "leads" the other, and such leading variables are extremely useful for forecasting purposes. Therefore, an examination of causal relationship between interest rates and housing prices is very important to real estate investors and real estate portfolio managers. An expanded version of a test originally developed by Granger (1969) and popularised by Sim (1972) was employed to see if real interest rates "Granger-cause" changes in housing prices. We run: 


$$
R P=f\left(R P_{t-1}, R P_{t-2}, \ldots, R P_{t-p}, R I_{t-1}, R I_{t-2}, \ldots, R I_{t-p}\right)
$$

where RP is the housing price changes in percent, or (Price ${ }_{t+1}-$ Price $_{t}$ ) / Price ${ }_{t} \mathrm{X}$ $100 \%$; and $\mathrm{RI}$ is the real interest rates, or $[(1+$ interest rate $) /(1+$ inflation rate $)]-1$. We used $F$-tests to test the null hypothesis that a pair of lag coefficients of RIs jointly equal zero. If we can reject the null hypothesis, then we have evidence that RI "Granger causes" RP. Note that if $p=1$, Equation (2) is similar to a Koyck distributed lag model. We ran two Granger tests, one in each direction. That is we ran Equation (2) and also ran:

$$
\mathrm{RI}=\mathrm{f}\left(\mathrm{RP}_{\mathrm{t}-1}, \mathrm{RP}_{\mathrm{t}-2}, \ldots, \mathrm{RP}_{\mathrm{t}-\mathrm{p}}, \mathrm{RI}_{\mathrm{t}-1}, \mathrm{RI}_{\mathrm{t}-2}, \ldots, \mathrm{RI}_{\mathrm{t}-\mathrm{p}}\right)
$$

testing for Granger causality. If the $F$-test is significant for Equation (2), but not for Equation (3), then we can conclude that RI "Granger causes" RP.

\section{Data sources}

Transaction-based quarterly data on housing prices in the private sector are based on property indices in the Hong Kong Property Review (various issues) constructed by the Rating and Valuation Department, the Government of the Special Administrative Region (HKSAR), People's Republic of China (PRC). The data are the most systematic and reliable source available for the Hong Kong real estate markets. The Best Lending Rate quoted by the Hong Kong and Shanghai Banking Corporation Limited in Hong Kong was used as the nominal interest rate. The rate of change of Consumer Price Index A (CPI(A)) as the inflation rate was obtained from the Hong Kong Monetary Authority and the Census and Statistics Department, HKSAR, PRC. Levels of housing prices are expressed in indices (based on $1989=100$ ) during the period; CPI(A) in year-onyear rates of change in percents; and market interest rates in percents per annum. The descriptive statistics of the variables are presented in Table 1.

Table 1: Descriptive statistics of variables

\begin{tabular}{lccccc}
\hline Variables & N & Min. & Max. & Mean & Std. Dev. \\
\hline Pr & 84 & 38.00 & 433.00 & 166.85 & 112.60 \\
Int-Rate & 84 & 5.24 & 34.90 & 9.73 & 3.97 \\
Inf-Rate & 84 & -5.00 & 16.40 & 6.45 & 4.92 \\
Real-Int & 84 & -3.21 & 26.20 & 3.27 & 4.95 \\
\hline Notes: & \\
Std. Dev. = Standard Deviation \\
Pr=Levels of housing price indices \\
Int-Rate = Nominal interest rates \\
Inf-Rate = Inflation rates \\
Real-Int = Real interest rates
\end{tabular}

Pacific Rim Property Research Journal, Vol 9 No 3 


\section{RESULTS AND FINDINGS}

The empirical results of the study are as follows:

\section{Unit root test}

Results of the Unit Root (ADF) Test for stationarity are reported in Table 2.

Table 2: Results of unit root (ADF) test

\begin{tabular}{|c|c|c|c|c|c|c|}
\hline & \multicolumn{3}{|c|}{ At the Level (Trend) } & \multicolumn{3}{|c|}{ First Differenced (No Trend) } \\
\hline Variables & $\mathbf{n}$ & ADF & $\mathbf{D W}$ & $\mathbf{n}$ & ADF & $\mathbf{D W}$ \\
\hline Pr & 1 & -1.967 & 1.996 & 0 & $-4.176^{*}$ & 1.919 \\
\hline Int-Rate & 1 & $-3.489 * *$ & 2.149 & 0 & $-16.201 *$ & 2.326 \\
\hline Inf-Rate & 1 & -1.734 & 2.024 & 0 & $-6.918 *$ & 1.995 \\
\hline Real-Int & 1 & -2.416 & 2.131 & 0 & $-14.567 *$ & 2.224 \\
\hline \multicolumn{7}{|c|}{$\begin{array}{l}\text { Notes: } \\
\operatorname{Pr}=\text { Levels of housing price indices } \\
\text { Int-Rate }=\text { Nominal interest rates } \\
\text { Inf-Rate }=\text { Inflation rates } \\
\text { Real-Int }=\text { Real interest rates } \\
\text { The critical values of ADF statistics with trend are: }-4.073,-3.465 \text {, and }-3.250 \text { at } 1 \%, 5 \% \text {, and } \\
10 \% \text { levels of significance respectively. } \\
\text { The critical values of ADF statistics with no trend are: }-3.511,-2.897 \text {, and }-2.585 \text { at } 1 \%, 5 \% \text {, } \\
\text { and } 10 \% \text { levels of significance respectively. } \\
*, * * \text {, and } * * * \text { indicate significance at the } 1 \%, 5 \% \text {, and } 10 \% \text { levels respectively. }\end{array}$} \\
\hline
\end{tabular}

In Table 2, the null hypothesis of a unit root, in level form, is not rejected, except for Int-Rate, which is marginally rejected at the 0.05 level of significance, when the computed absolute ADF test statistics associated with the numerical coefficients of Pr, Int-Rate, Inf-Rate, and Real-Int are compared with the absolute critical "tau" values of $-4.073,-3.465$, and -3.250 at the $0.01,0.05$, and 0.10 levels of significance. Since the Trend-Stationary Process does not succeed, the four series data were then first differenced and the Unit Root Test was re-run using the Difference Stationary Process. In this form, we can conclude to reject the null hypothesis of a unit root, suggesting that the variables are basically $I(1)$, stationary at the first-differenced level. It is also clear that the Durbin-Watson Tests were passed (the DW statistic lies between 1.59 and 2.41). We cannot reject the null hypothesis of no autocorrelation.

\section{Correlation of variables}

The linear relationships between variables were assessed. The Pearson correlations and significance levels are presented in Table 3. 
Levels of housing price indices (Pr) display higher correlations with nominal interest rates (Int-Rate) in 1998-2001 than in 1981-1997 (compare 0.678 in 19982001 with -0.322 in 1981-1997). This implies that low interest rates accompany low prices in the post-1997 period, as opposed to the inverse relationship in the pre-1997 period. In 1998-2001, the positive association between Pr and inflation rates (Inf-Rate) is even greater at 70 percent (0.692). However, in 1981-1997, the negative association is very weak at -9 percent $(-0.089)$. All correlations between Pr and Int-Rate in all periods are statistically significant at the 0.01 level.

Table 3: Pearson correlation matrix of variables

\begin{tabular}{|c|c|c|c|c|c|}
\hline Periods & Variables & Pr & Int-Rate & Inf-Rate & Real-Int \\
\hline \multirow[t]{5}{*}{$\begin{array}{c}1981-2001 \\
(\mathrm{~N}=84)\end{array}$} & $\begin{array}{c}\mathbf{P r} \\
\text { Sig. (2-tailed) }\end{array}$ & $\begin{array}{c}1.000 \\
-\end{array}$ & & & \\
\hline & $\begin{array}{c}\text { Int-Rate } \\
\text { Sig. (2-tailed) }\end{array}$ & $\begin{array}{c}{[-0.321]} \\
0.003\end{array}$ & $\begin{array}{c}1.000 \\
-\end{array}$ & & \\
\hline & $\begin{array}{c}\text { Inf-Rate } \\
\text { Sig. (2-tailed) }\end{array}$ & $\begin{array}{c}{[-0.285]} \\
0.009\end{array}$ & $\begin{array}{c}0.396] \\
0.000\end{array}$ & $\begin{array}{c}1.000 \\
-\end{array}$ & \\
\hline & Real-Int & 0.025 & {$[0.410]$} & {$[-0.676]$} & 1.000 \\
\hline & Sig. (2-tailed) & 0.821 & 0.000 & 0.000 & - \\
\hline \multirow[t]{4}{*}{$\begin{array}{c}1981-1997 \\
(\mathrm{~N}=68)\end{array}$} & $\begin{array}{c}\mathbf{P r} \\
\text { Sig. (2-tailed) }\end{array}$ & $\begin{array}{c}1.000 \\
-\end{array}$ & & & \\
\hline & $\begin{array}{c}\text { Int-Rate } \\
\text { Sig. }(2-\text { tailed })\end{array}$ & $\begin{array}{c}{[-0.322]} \\
0.007\end{array}$ & $\begin{array}{c}1.000 \\
-\end{array}$ & & \\
\hline & $\begin{array}{c}\text { Inf-Rate } \\
\text { Sig. (2-tailed) }\end{array}$ & $\begin{array}{l}-0.089 \\
0.468 \\
\end{array}$ & $\begin{array}{c}{[0.485]} \\
0.000\end{array}$ & $\begin{array}{c}1.000 \\
-\end{array}$ & \\
\hline & $\begin{array}{c}\text { Real-Int } \\
\text { Sig. (2-tailed) }\end{array}$ & $\begin{array}{c}<-0.283> \\
0.019 \\
\end{array}$ & $\begin{array}{c}{[0.713]} \\
0.000 \\
\end{array}$ & $\begin{array}{c}<-0.267> \\
0.027 \\
\end{array}$ & $\begin{array}{c}1.000 \\
-\end{array}$ \\
\hline \multirow[t]{4}{*}{$\begin{array}{c}1998-2001 \\
(\mathrm{~N}=16)\end{array}$} & $\begin{array}{c}\mathbf{P r} \\
\text { Sig. (2-tailed) }\end{array}$ & $\begin{array}{c}1.000 \\
-\end{array}$ & & & \\
\hline & Int-Rate & [0.678] & 1.000 & & \\
\hline & $\begin{array}{c}\text { Sig. (2-tailed) } \\
\text { Inf-Rate } \\
\text { Sig. (2-tailed) }\end{array}$ & $\begin{array}{c}0.004 \\
0.692] \\
0.003\end{array}$ & $\begin{array}{c}- \\
0.48 \\
0.060\end{array}$ & $\begin{array}{c}1.000 \\
-\end{array}$ & \\
\hline & $\begin{array}{c}\text { Real-Int } \\
\text { Sig. (2-tailed) }\end{array}$ & $\begin{array}{c}-0.423 \\
0.102 \\
\end{array}$ & $\begin{array}{l}-0.010 \\
0.969 \\
\end{array}$ & $\begin{array}{c}-0.882] \\
0.000 \\
\end{array}$ & $\begin{array}{c}1.000 \\
-\end{array}$ \\
\hline $\begin{array}{l}\text { Notes: } \\
\text { Pr }=\text { Lev } \\
\text { Int-Rate } \\
\text { Inf-Rate } \\
\text { Real-Int } \\
\text { [ ] Corr } \\
<>\text { Cor }\end{array}$ & $\begin{array}{l}1 \text { of housing price } \\
=\text { Nominal interest } \\
=\text { Inflation rates } \\
=\text { Real interest rate } \\
\text { ation is significan } \\
\text { lation is significa }\end{array}$ & $\begin{array}{l}\text { at the } 0.01 \text { le } \\
\text { at the } 0.05\end{array}$ & $\begin{array}{l}\text {-tailed) } \\
\text { 2-tailed) }\end{array}$ & & \\
\hline
\end{tabular}


It should be noted that the correlation coefficients between Int-Rates and Inf-Rates are less than 0.5 in all periods (0.396 in 1981-2001, 0.485 in 1981-1997 and 0.480 (not significant) in 1998-2001), indicating that there is no strong linear association, or potentially harmful multi-collinearity.

For comparison and crosschecking purposes, we also computed the nonparametric Spearman correlation for 1998-2001 with a sample of only 16 quarterly data sets. The results are shown in Table 3a below.

Table 3a: Spearman rank-correlation matrix of variables

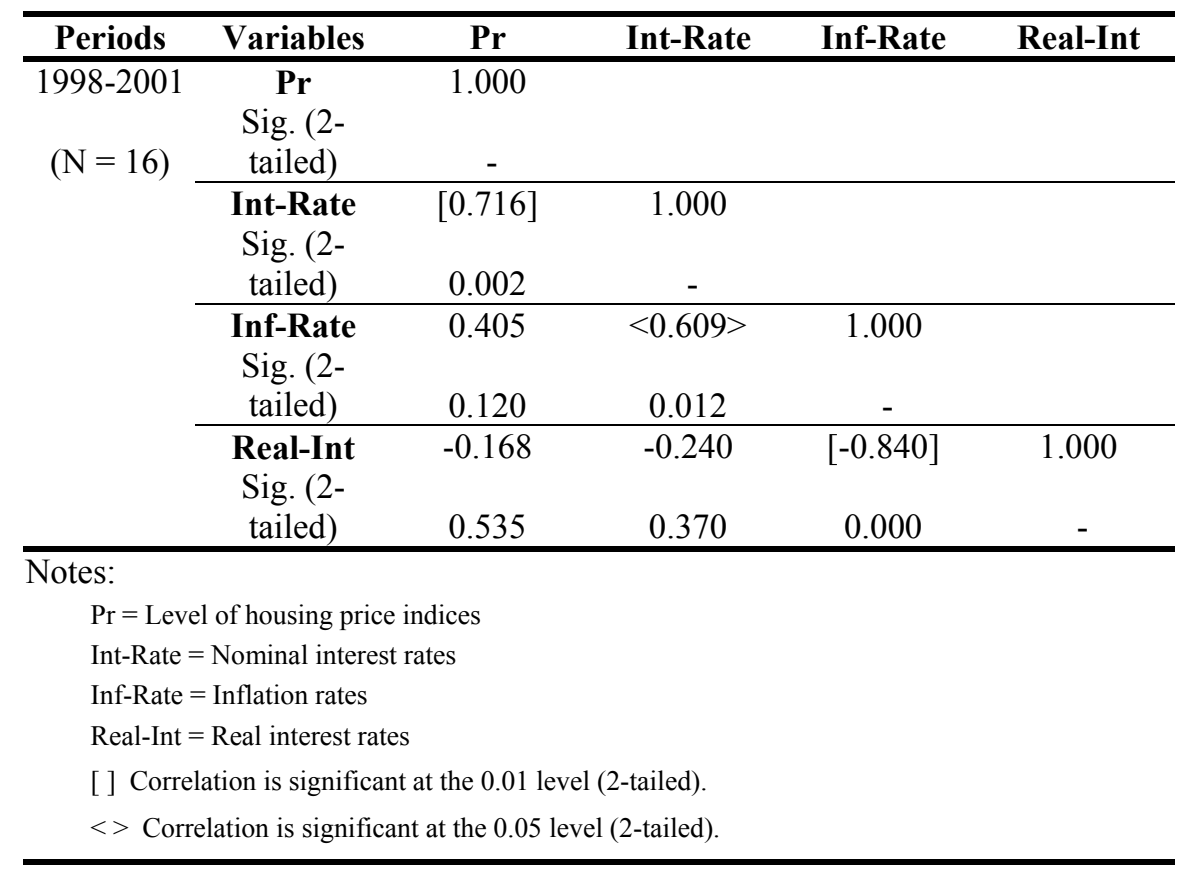

As shown, the correlations obtained from the Pearson and Spearman analyses are similar. The directions, both positive and negative, of the relationship are identical. When using the non-parametric test for 1998-2001, the positive Pr and Int-Rate relationship is slightly stronger at the 0.01 level (compare coefficients 0.716 in Table 3a (Spearman) and 0.678 in Table 3 (Pearson). In sum, the parametric and non-parametric correlations are consistent. 


\section{Housing prices regressed on changes in market interest rates}

and/or inflation rates

The results of the bivariate regression are shown in Table 4 below.

Table 4: Linear regression of housing prices

\begin{tabular}{lcccccccc}
\hline \multicolumn{1}{c}{ Period } & Indep. Var. & Constant & Coeff. & t & df & Sig. & R Sq. & F \\
\hline 1981-2001 & Int-Rate & 255.421 & -9.107 & -3.072 & 83 & 0.003 & 0.103 & 9.435 \\
by Quarters & Inf-Rate & 208.949 & -6.526 & -2.692 & 83 & 0.009 & 0.081 & 7.246 \\
& Real-Int & 164.980 & 0.571 & 0.227 & 83 & 0.821 & 0.001 & 0.052 \\
\hline $1981-1997$ & Int-Rate & 234.274 & -8.614 & -2.765 & 67 & 0.007 & 0.104 & 7.643 \\
by Quarters & Inf-Rate & 175.537 & -3.283 & -0.729 & 67 & 0.468 & 0.008 & 0.532 \\
& Real-Int & 162.358 & -8.348 & -2.400 & 67 & 0.019 & 0.080 & 5.759 \\
\hline 1998-2001 & Int-Rate & 52.477 & 22.375 & 3.455 & 15 & 0.004 & 0.464 & 11.939 \\
by Quarters & Inf-Rate & 260.718 & 10.767 & 3.582 & 15 & 0.003 & 0.478 & 12.832 \\
& Real-Int & 320.973 & -7.510 & -1.747 & 15 & 0.102 & 0.179 & 3.053 \\
\hline \\
Notes:
\end{tabular}

The regressions show that in 1981-2001, a decrease in interest rate is, in overall terms, accompanied by higher housing prices. The effect is also pronounced in the 1981-1997 sub-period. This apparent inconsistency lies in Fisher's hypothesis of "low" interest rates accompanying "low" prices. The pattern of negative coefficients of nominal interest rates is consistent with the real situation: falling interest rates stimulated property prices before 1997. The goodness of fit of the estimated price-nominal rate equations in 1981-2001 and 1981-1997 is poor, as the coefficient of determination, $\mathrm{R}^{2}$ is very low (about 10 percent). The coefficients of nominal rates in both periods are significantly different from zero at the 0.05 level $(\mathrm{p}=0.007)$.

An important finding is the reversal of the pre-1997 period: the post-1997 period saw a direct relationship. This is in line with the findings of Gibson (1970) and Fisher (1930). A decrease in nominal interest rates correspondingly brought about a greater decrease in housing prices, hence a greater (and negative) impact than in the pre-1997 period. (Compare the coefficients of 22.375 in 1998-2001 with -8.614 in 1981-1997.) The nominal interest rate accounts for about 46 percent $\left(\mathrm{R}^{2}\right.$ $=0.464)$ of the variance in price changes in 1998-2001. The goodness of fit is considered moderate. The estimated coefficients in the nominal rate equations are significant at the 0.01 level in all periods. 
Similarly, the key point lies in the fact that a decrease in inflation rates also led to a great decrease in housing prices in the post-1997 period but an increase in price in the earlier period. (Compare the coefficient of 10.767 in 1998-2001 with -3.283 in 1981-1997.) In the combined period of 1981-2001, overall, we see an inverse relationship between housing prices and inflation rates (refer to the coefficient of -6.526). Pooling the data for prices and inflation rates of these two periods is valid, since we cannot reject the null hypothesis of no differences in the parameters and variances of the error terms of these two models. The price functions of the two periods of 1981-1997 and 1998-2001 are identical, since the Chow Test, which will be discussed later, is significant at the 0.05 level.

The optimising behavior of a representative investor ensures that the equilibriumhousing price is forward looking. It depends solely on the user cost of capital, rent, and tax elements, as for other assets. In the deflationary 1998-2001, investors' hope-led expectations of housing prices and rents were weak, and thus contributed to a slow market. As there are usually small variations in interest rates and tax rates in the long run, the user cost should remain fairly stable, all others being equal. However, when the appreciation of housing price contains the bubble, expectation for advance-in-price becomes reversed in the deflationary period. Thus, the anticipated capital losses will increase the magnitude of the denominator in the user cost equation in Footnote 3, hence lowering the capital value of the income property.

On this basis, these results lead us to infer that a fall in market interest rate in 1998 - 2001 would no longer stimulate housing prices, all other things being equal. The positive effect of falling interest rates has likely been offset. Nevertheless, an increase in real interest rates resulting from deflation would give rise to lower housing prices. (Note the negative coefficients $(-7.510)$ in the real interest rate equation in 1998-2001 in Table 4 above). From this, it is increasingly apparent that the interaction between nominal rates (where the sign of the coefficient is indeterminate ${ }^{5}$ ) and expectations of capital gains or losses plays an important role in the determination of housing prices.

Using the same three study periods, the dependent variable "Levels of Housing Prices" was regressed against "Nominal Interest Rates" and "Inflation Rates". The regression results are presented in Table 5.

\footnotetext{
${ }^{5}$ It is because when interest rates rise, the housing supply curve shifts upward to the left, while the housing demand curve shifts downward to the left. The net impact on housing prices and interest rate coefficient depends on the relative shifts of the demand and supply curves.
} 
Again, similar to the bivariate regression, the pre-1997 period displays an inverse relationship between housing prices and nominal rates. In 1998-2001, there is, however, a positive relationship, indicating that a fall in interest rates does not actually raise property prices. Our results agree quantitatively with the general trend of low interest rates accompanying low prices in the disinflationary/ deflationary period after 1997, as opposed in the pre-1997 period. This trend is consistent with Fisher's hypothesis. With an additional explanatory variable of "Inflation Rates", the fit of the 1998-2001 estimated equation is improved to $\mathrm{R}^{2}=$ 0.634 (compare 0.464 in Table 4 above). The coefficients of interest rates are, again, significant at the 0.05 level. It should be noted that the least squared estimators in the regression for 1998-2001 may be biased and inconsistent as we conclude to reject the null hypothesis of no structural change in the two periods of the data (see the Chow Test below).

Table 5: Relation between levels of housing prices, nominal interest rates and inflation rates

I. Quarterly Observations, 1981-2001

$$
\begin{gathered}
\operatorname{Pr}=262.651-7.008 * \text { Int-Rate }-4.286 \text { Inf-Rate } \\
{[-2.194] \quad[-1.661]} \\
\text { R-squared }=0.133 ; \text { S.E. }=106.1480 ; \mathrm{df}=83
\end{gathered}
$$

\section{Quarterly Observations, 1981-1997}

$$
\begin{gathered}
\operatorname{Pr}=218.932-9.751 * \text { Int-Rate }+3.216 \text { Inf-Rate } \\
{[-2.724] \quad[0.654]} \\
\text { R-squared }=0.110 ; \text { S.E. }=111.0055 ; \mathrm{df}=67
\end{gathered}
$$

III. Quarterly Observations, 1998-2001

$$
\begin{gathered}
\operatorname{Pr}=127.756+14.853 * \text { Int-Rate }+7.404 * \text { Inf-Rate } \\
{[2.357] \quad[2.488]}
\end{gathered}
$$

R-squared $=0.634 ;$ S.E. $=28.9585 ; \mathrm{df}=15$

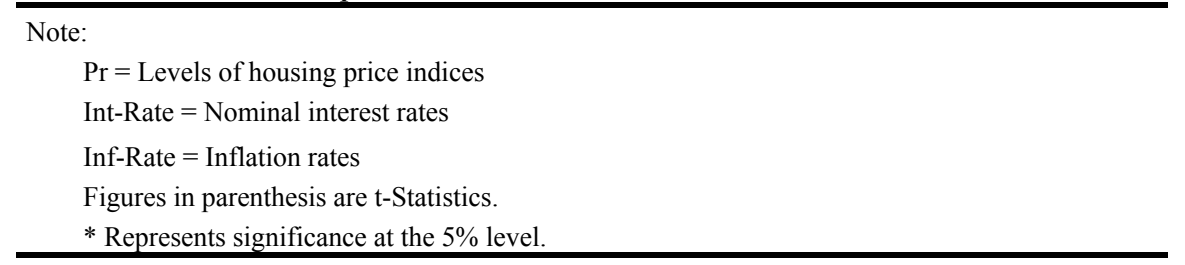




\section{The Chow test}

Table 6 shows the results of the Chow test for structural breaks.

Table 6: Chow Test of structural breaks: cross section data

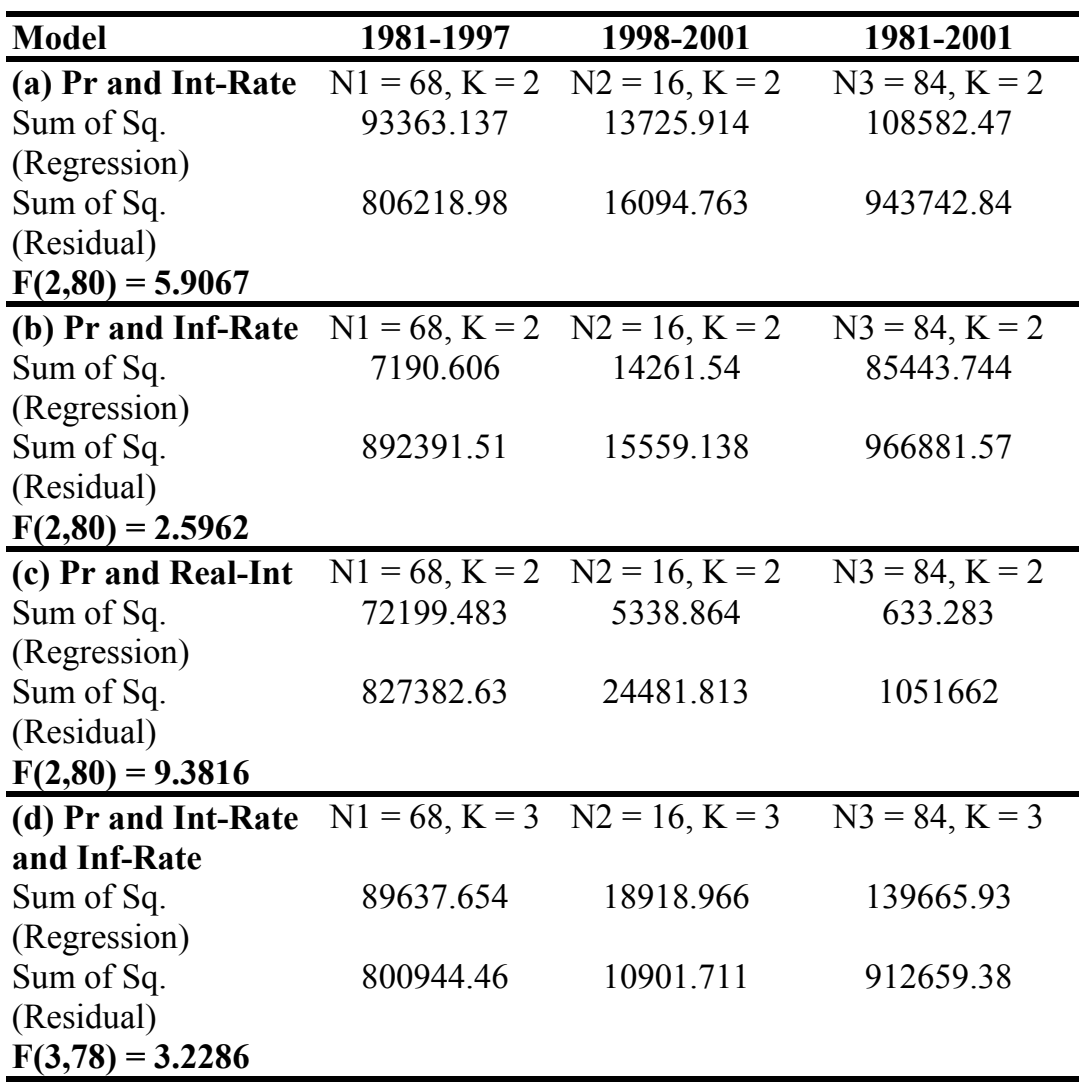

As shown, only in the regression Pr and Inf-Rate, the $F_{\text {calculated }}(2.5962)$ is smaller than the critical value, ${ }_{(0.05)} \mathrm{F}_{(2,80)}$ of 3.1233 . Therefore, we cannot reject the null hypothesis at the 0.05 level that the functions of the two periods are identical. In other words, there exists structural changes in other regression parameters. Similarly, there are structural changes in Pr, Int-Rate, and Inf-Rate as the $\mathrm{F}$ calculated of 3.2286 is greater than the critical ${ }_{(0.05)} \mathrm{F}_{(3,78)}$ of 2.736. These regressions of the pooled data are somewhat inadequate.

\section{Granger causality between variables}

Table 7 presents the results of the Granger causality tests of the variables RI and RP. From the $F$ statistics, the null hypothesis of no causal effects running from RI 
to RP or RP to RI in the sample cannot be rejected in all periods when the test is fitted with Best Lending Rates as interest rates. This is in contrast to the findings of Tan's (1994) unidirectional causality running from housing prices to interest rates in Singapore. However, the causal effects running from RI to RP and from RP to RI in both $1998-2001^{6}$ and $1981-2001$ periods are supported at the 0.01 and 0.05 levels respectively, when Saving Rates were used as a proxy of interest rate instead. Thus, these findings could be interpreted that there are no feedback effects between PR and RI, using Best Lending Rates as interest rates in Hong Kong. In the Granger sense, RI does not affect PR, nor does PR lead RI for the past two decades.

Table 7: Granger - causality results ${ }^{\text {a }}$

\begin{tabular}{|c|c|c|c|c|}
\hline Period & Data Frequency & $\begin{array}{c}\text { Direction of } \\
\text { Causality }\end{array}$ & $F$ Statistic & p value \\
\hline \multicolumn{5}{|c|}{ I. Using the Best Lending Rates as interest rates } \\
\hline \multirow[t]{2}{*}{$1981-2001$} & Monthly \& quarterly & RI ---> RP & 2.11 & 0.1431 \\
\hline & & RP ---> RI & 5.10 & 0.0781 \\
\hline \multirow[t]{2}{*}{$1981-1997$} & Quarterly & RI ---> RP & 1.71 & 0.2119 \\
\hline & & RP ---> RI & 4.49 & 0.1057 \\
\hline \multirow[t]{2}{*}{$1998-2001$} & Monthly & RI ---> RP & 0.63 & 0.5454 \\
\hline & & RP ---> RI & 1.60 & 0.4488 \\
\hline \multicolumn{5}{|c|}{ II. Using the Saving Rates as interest rates } \\
\hline \multirow[t]{2}{*}{$1981-2001$} & Quarterly & RI ---> RP & $3.54 * *$ & 0.0427 \\
\hline & & RP ---> RI & $8.34 * *$ & 0.0154 \\
\hline \multirow[t]{2}{*}{$1981-1997$} & Quarterly & RI ---> RP & 0.81 & 0.4574 \\
\hline & & RP ---> RI & 1.99 & 0.3697 \\
\hline \multirow[t]{2}{*}{$1998-2001$} & Quarterly & RI ---> RP & $2.48^{*}$ & 0.0000 \\
\hline & & RP ---> RI & $2.98 *$ & 0.0000 \\
\hline
\end{tabular}

${ }^{a}$ The null hypothesis of no causality is rejected if $F$ statistic exceeds the critical value or $\mathrm{p}$ is less than 0.01 . * and ** indicate, respectively, the "Granger-causality" is significant at the 0.01 and 0.05 levels.

\footnotetext{
${ }^{6}$ One may argue that the results for 1998-2001 might be generally inconclusive because the sample is small $(\mathrm{N}=16)$. Durbin-Watson table lists the smallest sample is 15 . The results can be considered marginally conclusive and indicative. Many statisticians believe the sample should be at least 50 for the test to produce worthwhile results.
} 
The significant finding is that interest rates are not a leading impact on housing prices; in particular, falling interest rates do not necessarily stimulate property prices, especially in the post-1997 period. One would forcibly argue that the improved "affordability" of house owners (as a result of falling interest rates) have been undermined by current high unemployment and salary cuts. However, this does not provide a full explanation to the slow market from expectation perspectives as hope-led expectations have not been taken into consideration. The main cause for the current slow market is the weak expectations of housing prices and rents in Hong Kong. Low expectations discourage housing consumption and investment, and depress real asset values.

\section{IMPLICATIONS}

This paper has investigated the role of interest rates on housing prices from expectation perspectives. Our empirical results suggest that the interest rate effect on housing prices in Hong Kong differs significantly: positive in the inflationary pre-1997 period, and negative in the deflationary post-1997 period. The negative impact is greater than the positive one after the structural shift around 1997. There also exists a higher correlation between housing prices and nominal interest rates or inflation rates in 1998-2001 relative to those in 1981-1997. Further, interest rates do not affect housing prices in the Granger sense.

It is true that "low" interest rates accompany "low" prices, originally hypothesised by Fisher. This holds true for the post-1997 period, but not in the early 1990s when the interest rates were low, coupled with fuelling expectations of continued higher inflation. This had a major positive effect on higher housing prices before 1997. The study, nonetheless, supports that lower and falling interest rates since 1998 have been strongly correlated with a low level of housing prices, the Gibson paradox, as Keynes (1930) named it. ${ }^{7}$ One important implication of the finding is that low interest rates do not necessarily lead to higher housing prices in periods of falling real prices, all else being equal. It is particularly evidenced in times of deflation after 1997. In the long run, housing prices rise as inflation continues. Most of the fall in housing prices in the post-1997 period are attributed to weak price expectations. Investors factor possible capital losses into their willingness to buy real property. Their low expectations become self-fulfilling. The result is that weak expectations continue to exert a prompt and dampening effect on the

\footnotetext{
${ }^{7}$ Keynes (1930) named the high correlation between aggregate level of commodity prices and interest rates the Gibson paradox (after a businessman called A. H. Gibson had written several articles on the correlation between interest rates and prices), since it seemed to contradict the prediction of classical monetary theory that the interest rate is independent of the price level.
} 
demand for housing, and in the short run, further decreases in interest rates do not accompany higher housing prices.

\section{CONCLUSION}

In essence, price changes can be explained by the interaction of nominal rates and price expectations, the real rate to the borrower, that affects housing prices. It can be broadly concluded that the dampening effect arising from weak price expectations tends to be more substantial in the deflationary period. The total positive effect of low interest rates is offset by an expectation of capital losses among housing consumers. This is in sharp contrast with low interest rates being accompanied by higher housing prices in the pre-1997 period, as people simply expected prices to rise. Therefore, under this self-fulfilling expectations, not even the significant falls in nominal interest rates that took place in 2001 were sufficient to revive housing prices in Hong Kong, as people, again, expected housing prices continue to fall. The study suggests, however, that price expectations play a critical role in housing price fluctuations in the short run. Finally, it would seem that the interest rate alone might not be useful in predicting the level of housing prices. The movements of interest rates may occasionally give misleading signals about the direction and extent of movements in housing prices beyond rational limits.

\section{REFERENCES}

Blackadar, C. (1989), Dynamic capitalization: an income approach in real dollars at real interest, Part 3: the dynamic of expectations. The Appraisal Journal, July, 338-71.

Brown, J., Song, H. and McGillivray, A. (1997), Forecasting UK house prices: a time varying coefficient approach. Economic Modeling, 14, 529-48.

Capozza, D. (1996), Expectations, efficiency, and euphoria in the housing market. Regional Science and Urban Economics, 26, 369-86.

Census and Statistics Department, The Government of HKSAR, PRC. Hong Kong Monthly Digest of Statistics (various issues). Hong Kong: Government Printer.

Chow, G. (1960), Tests of equality between sets of coefficients in two linear regression. Econometrica, 28, 591-605. 
DeGolyer, M. et al. (2001), The Hong Kong Transition Project: 1982 - 2007. Hong Kong: Hong Kong Baptist University.

DiPasquale, D. and Wheaton, W. (1994), Housing market dynamics and the future of housing prices. Journal of Urban Economics, 35, 1-27.

Fisher, I. (1930), The Theory of Interest. New York: Macmillan.

Granger, C. (1969), Investigating causal relationship by econometric methods and cross- spectral methods. Econometrica, 34, $424-38$.

Granger, C. and Newbold, P. (1974), Spurious regressions in econometrics. Journal of Econometrics, 2(2), 111-20.

Harris, J. (1989), The effect of real rate of interest on housing prices. Journal of Real Estate Finance and Economics, 2(1), 47 - 60.

Jud, G. and Winkler, D. (2002), The dynamics of metropolitan housing prices. Journal of Real Estate Research, 23(1/2), 29-45.

Keynes, J. (1930), A Treatise on Money. Vol. II. London: MacMillan and Company.

Kim, K. H. and Suh, S. H. (1993), Speculation and price bubbles in the Korean and Japanese real estate markets. Journal of Real Estate Finance and Economics, $6,73-87$.

Krashinsky, M. and Milne, W. (1987), Housing price in metropolitan Toronto. Regional Science and Urban Economics, 17, 289-305.

Land Registry, The Government of the Special Administrative Region, People's Republic of China. "Agreements for Sale and Purchase of Building Unit". Hong Kong: Government Printer.

McDonald, J. (1985), Expectations and urban housing prices. Urban Studies, 22, 543-49.

Mills, E. and Hamilton, B. (1984), Urban Economics. New York: Scott Foresman, $4^{\text {th }}$ edn., $189-90$.

Muth, R. (1986), Expectations of house-price changes. Papers of Regional Science Association, 59, 45-55. 
Muellauer, J. and Murphy, A. (1996), Booms and busts in the U.K. housing market. $6^{\text {th }}$ Real Estate Conference. AREUEA, June, U.C. Berkerley.

Peng, R. and Wheaton, W. (1994), Effect on restrictive land supply on housing in Hong Kong: an econometric analysis. Journal of Housing Research, 5, 263 - 91.

Phillips, R. (1988), Residential capitalization rate: explaining inter-metropolitan variation, 1974 - 1979. Journal of Urban Economics, 23, 278 - 90.

(1985), The relationship between residential rents and house values: explaining intertemporal and cross-sectional variation, $1974-1979$. US Department of Housing and Urban Development, Office of Policy Development and Research, Research Utilization Division.

Rating and Valuation Department, The Government of HKSAR, PRC. Hong Kong Property Review (various issues). Hong Kong: Hong Kong Government Printer.

Sim C. (1972), Money, income and causality. American Economic Review, 62, 540-52.

Tan, W. (1994), Housing prices and rapid growth. Journal of Real Estate and Construction, 4, 1-15.

Tse, R. (1996), Mortgage default risk and lending policy - a study of mortgage lending in Hong Kong. Australian Land Economic Review, 2(2).

(1996a), Housing return and the determinants of capitalization rates with reference to Hong Kong. Journal of Property Research, 13(2), 115 - 29.

(1996b), Relationship between Hong Kong house prices and mortgage flows under deposit-rate ceiling and linked exchange rate. Journal of Property Finance, $7(4), 54-63$. 